Brown expressed concern that the House would only support the Freedom-based Space Station option and that the project is in risk of being scrapped altogether.

Commenting on the NASA Authorization Bill, Ralph Hall (D-Tex.), chairman of the Space Subcommittee, said it is a responsible one. "It preserves a balanced and vital aeronautics and space program and provides a good value to the American taxpayer," he noted.

The House Science, Space and Technol ogy Committee is scheduled to hold hearings to review results of the redesign process on June 8 , after the design review is complete. The committee will begin mark up of the bill on June 9. NASA's study is expected to be reviewed by an outside panel of experts on June 10, when President Clinton will select one of the redesign options.Susan Bush

\section{IDEAL Symposium on the East African Lakes}

\section{PAGES 250-251}

A vast array of interdisciplinary problems presented by the African Great Lakes were highlighted at the International Symposium on the Limnology, Climatology and Paleoclimatology of the East African Lakes, organized by the International Decade for the East African Lakes (IDEAL) February 17-21 in Jinja, Uganda. Approximately 125 scientists attended from North America, Europe, Africa, and New Zealand. Jinja is located on the northern shore of Lake Victoria at the headwaters of the Nile and is the site of the host institution for the symposium, the Uganda Freshwater Fisheries Research Organization (UFFRO). The conveners of the symposium were Tom Johnson of Duke University, George Kitaka of UNESCO-ROSTA, and Eric Odada of the University of Nairobi.

Physical processes are unique in these tropical lakes, where Coriolis force is low and prevailing winds are unidirectional for extended periods of time. The lakes' chemistry is strongly affected by biological and perhaps geothermal processes and shows remnants of past low-stand conditions.

Biological food webs unlike any others found on the planet have evolved. Tracing of rates and spatial patterns of speciation of endemic fishes by DNA sequencing have begun and are found to contain some surprises. The paleoclimatic record in the lake sediments archives a history of the Intertropical Convergence Zone and the Earth's tropical heat engine. It is beginning to reveal some abrupt changes not only during the transition from the last glacial maximum, but also within the Holocene.

Twenty-seven oral presentations and forty-two posters provided overviews and the latest results of African climatological and limnological research over the past decade. The secluded location in Jinja provided an excellent opportunity to examine in-depth topics ranging from tectonics to aquatic biology, chemistry and physics, modern climate dynamics, anthropogenic impact, evolutionary biology, and paleoclimatology.
Jean-Jacques Tiercelin of the University Bretagne Occidentale reviewed the tectonic setting, stressing the importance of the three northwest-southeast trending transform zones linking the eastern and western branches of the rift valley, the structure and size of the half-graben units that comprise the building blocks of the rift basins, and the sediment thickness and estimated age of the different lake basins. Sharon Nicholson of Florida State University provided an overview of the climatic setting of East Africa, with special emphasis on rainfall anomalies in time and space, and the apparent connections of East African climate to sea-surface temperature anomaly patterns and the $\mathrm{El}$ Niño/Southern Oscillation. Nicholson stressed the spatial coherency of the African rainfall anomaly patterns and their strong dependence on the anomalies associated with the short rainy season. L. Ogallo, University of Nairobi, emphasized that East African climate is strongly tied to the behavior of the Intertropical Convergence Zone. Both Nicholson and Ogallo discussed the spectral peaks in rainfall and lake level variability at about $5.6,3.3$, and 2.5 years.

The physical limnology of the rift lakes was reviewed by Robert Spiegel of the University of Canterbury, New Zealand. He pointed out some of the major differences between the physics of the African great lakes and their North American counterparts, including the unidirectional nature of the wind field channeled through the rift valley, unlike the rotational nature of the wind vector that occurs over the span of a few days with passing fronts in the temperate latitudes. The vertical density structure is characterized by small temperature gradients but a large thermal expansivity. Consequently, the surface layer is subject to more intense convective mixing and is therefore usually deeper than the epilimnion of temperate lakes. Due to the great depth and wind forcing, the metalimnion also reaches deeper. Most of the water balance of the large African lakes is dominated by rainfall and evaporation, making them particularly susceptible to shifting between closed- and open-basin status with a slight change in annual rainfal and evaporation. The different basin morphologies and proximity to the equator provide unique opportunities to model fluid flow with varying boundary conditions and inertial periods that are hundreds of hours in duration. A. Wuest of ETH/EAWAG (Swiss Federal Technical Institute and Swiss Federal Water Research Institute), Switzerland, emphasized the importance of biogenically stimulated chemical density stratification in great depth of hypolimnia with small thermal density stratification. Since the deep-water temperature gradients of both lakes Malawi and Tanganyika are nearly adiabatic, the dissolved solids play an important role in their meromixis. Whereas the dissolved solids are solely responsible for the density stratification in the deepest $100 \mathrm{~m}$ in the less-deep Lake Malawi, the situation in Lake Tanganyika has not yet been studied.

The nutrient budget and nutrient profiles of Lake Tanganyika analyzed by John Ed- mond were presented by Ray Weiss of Scripps Institution of Oceanography. There are distinct differences in the profiles from the north versus south basins of the lake below the depth of their adjoining sill, perhaps reflecting different rates of methanogenesis or fluvial influx. Harmon Craig's isotope data from Lake Tanganyika was presented by Thure Cerling of the University of Utah. The isotopically heavy bottom waters of Lake Tanganyika reflect more saline and perhaps cooler conditions than present, and the ${ }^{4} \mathrm{He}$ profile shows a significant input of helium at a depth of $300-400 \mathrm{~m}$. Cerling also presented his results of pore-water chemistry from lakes Turkana and Malawi, showing evidence for methanogenesis, previous lowstands of the lakes and, in the case of Malawi, unusually high ammonium concentration in one of the cores. Weiss presented results of his transient tracers study in Lake Baikal and indicated how this approach could be used to investigate the residence time of the hypolimnetic waters of both Malawi and Tanganyika. Robert Hecky of the Canadian Freshwater Institute in Winnipeg discussed the nutrient profiles of lakes Tang anyika, Malawi, and Victoria, the relative sizes of the dissolved inorganic and organic pools of these nutrients, new productivity, and the importance of atmospheric deposition of nitrate.

John Lehman of the University of Michigan discussed the pelagic food webs of the large African lakes. Referring to the "endless summer" of the African tropical lakes, a term coined by Peter and Susan Kilham, he pointed out the significantly greater importance of biological over physical processes controlling the nutrient cycles. The onshoreto-offshore gradient in the importance of fish planktivory versus invertebrate predation affects size and body morphology among many of the zooplankton. Lehman also reviewed some of the major differences in the species composition of the food webs in the large East African lakes. Axel Meyer of SUNY Stony Brook presented an overview of the cichlid fish speciation in East Africa. Mitochondrial DNA analyses of the fish from the various lakes show patterns of common ancestry. The Lake Victoria cichlids are closely related to those found in the western rift lakes Albert and Edward and, surprisingly, are more closely related to those in Malawi than in Tanganyika. The reasons for this apparent geographic hop in evolution are not yet clear. The Victoria species flock appears to have evolved rapidly with no apparent evolutionary sequence - it may be no older than 200,000 years old.

Patterns of sedimentation in the rift lakes were described by Tom Johnson, who drew upon results from high-resolution seismic profiles and sediment coring. The large lakes have more complex patterns of sedimentation than the small, shallow lakes. Paleoclimate signals are encoded in the terrigenous, biogenous, and authigenic components of the sediments and are beginning to be interpreted on time scales ranging from millenia to seasons. Michael Talbot of the University of Bergen discussed the isotopic composi- 
tion of the organic matter accumulating in tropical lakes, emphasizing that although its signals of $\delta^{15} \mathrm{~N}$ and $\delta^{13} \mathrm{C}$ are complex, the organic component is always present and provides the best potential for continuous isotopic records from all lakes. Data presented from Lake Bosumtwi in Ghana and Lake Albert in the western arm of the rift valley demonstrated how the $\mathrm{C}$ and $\mathrm{N}$ records revealed changing lake conditions through the Holocene. Dan Livingstone, Duke University, presented a comprehensive engineering study of piston coring and argued for design of a corer weighing a ton that could recover 45-m-long cores from the soft sediments in the African lakes. He stressed the importance of anchoring a vessel for coring operations as well as the need to keep core wall thickness to an absolute minimum.

Paleoclimatological results were presented by several speakers. J. MworiaMaitima of the National Museums of Kenya summarized the Holocene fluctuations in the levels of several small Kenyan lakes, showing a coherent pattern of wet conditions between 6000 and 10,000 years ago followed by change to present-day conditions around 4000 years ago. A. J. Lema of the University of Dar es Salaam summarized the historical record of lake-level variability for the past century, showing a relatively steady decline in lake levels from 1900 to 1960 , the heavy rainfall throughout East Africa in 1961 causing lakes to rise for the following three years, and subsequent decline in lake levels since 1964. Overall, the pattern is one of slow decline in lake level interrupted by occasional abrupt rise. Kerry Kelts of the University of Minnesota placed the East African lakes in their global climatic setting and emphasized the need for multiproxy records that can be examined for abrupt change on a regional scale, with careful attention paid to leads and lags in the system. He examined several time windows of change, including the Little Ice Age, the Younger Dryas, and the Last Glacial Maximum. He also focused on the 4 k.y. B.P. level, at which time many of the North African lakes showed an abrupt shift to aridity, and other lakes in Europe and the Tibetan Plateau showed significant changes in isotopic composition of their sediments. Alan Perrott of Oxford University presented $\delta^{13} \mathrm{C}$ results from organic matter recovered in cores from two alpine lakes in East Africa, where he sees a shift to lighter values at about 15 and 11 k.y. B.P., perhaps reflecting shifts from $\mathrm{C} 4$ to $\mathrm{C} 3$ plants in the drainage basin.

The anthropogenic impact of man on the large African lakes was discussed by Andy Cohen of the University of Arizona. Population growth in the drainage basins of the large African lakes averages about 3.5\% per year. This exacerbates the pressures imposed upon the lakes from fishing, chemical pollution, introduction of exotic species of plants and animals, and watershed disturbance causing accelerated siltation in nearshore habitats. Craig Harris of Michigan State University elaborated on drainage basin disturbance caused by population growth and a shift from subsistence farming to export agri- culture, which has greater environmental impact.

Lake Victoria is undergoing the most dramatic change of the large East African lakes at the present time, partly in response to introduction of exotic species like the Nile perch and the water hyacinth, but perhaps also due to elevated nutrient influx from agricultural activity in the lake's drainage basin and climatic change. Gaspard Ntakimazi of the University of Burundi reviewed the fish catches of all of the large East African lakes and showed how the total yield from Lake Victoria has actually risen since 1984 due to the catch of Nile perch. However, it is not clear that this increased catch will be sustainable and, as pointed out by William Kudhongania of UFFRO, along with this increased catch has come a crash in haplochromid fish diversity, dropping from over 300 endemic species in the lake prior to 1984 to less than 150 today. Lake Victoria has also shown dramatic shifts in nutrient profiles, dissolved oxygen profiles, water clarity, and predominant algal producers in the past 30 years, as demonstrated by Fred Bugenyi of UFFRO.

The fourth day of the conference was devoted to further developing a science and implementation plan for IDEAL. Key scientific questions were developed within four subdisciplines (climate and physical limnology, biological processes and evolutionary biology, geochemistry, and paleoclimatology), along with recommendations for the field and laboratory analyses, data archiving, and logistical activities required to answer these questions. The science and implementation plan will be published in summer
1993 and will be available from the IDEAL Office at Duke University Marine Laboratory, Beaufort, NC 28516

The symposium ended with a banquet, which featured guest speaker E. B. Worthington reminiscing about his research activities on the large East African lakes in the late 1920 s and early 1930s. He told fascinating tales of the discovery of hundreds of new species of fish on lakes Victoria, Edward, and Albert; of coercing the African King's Rifles to provide logistical assistance on Lake Rudolph; and of establishing the fisheries research laboratories at Jinja, Kisumu, and other key sites on the African lakes. Following Worthington's talk, acknowledgment was extended to the sponsors of the meeting, the National Science Foundation, NASA, the Regional Office for Science and Technology in Africa of UNESCO, UNEP, the International Geosphere Biosphere Program, and the Societas Internationalis Limnologiae.

We have learned much in the past 65 years, but it is clear that we have only begun to tap the wealth of knowledge about the evolution of life, climate, and aquatic systems that can be gained from a major scientific initiative on the oldest tropical lakes on Earth.

A symposium volume containing the manuscripts of all of the invited speakers and most of the poster presentations will be published this year.-T. C. Johnson, Duke University Marine Laboratory, Beaufort, N.C., K. Kelts, Limnological Research Center, University of Minnesota, Minneapolis; J. T. Lehman, Department of Biology, University of Michigan, Ann Arbor; and A. Wuest, Umweltphysik, ETH/EAWAG, Dubendorf, Switzerland

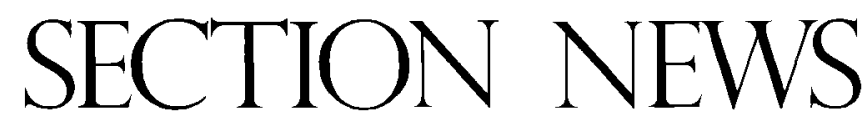

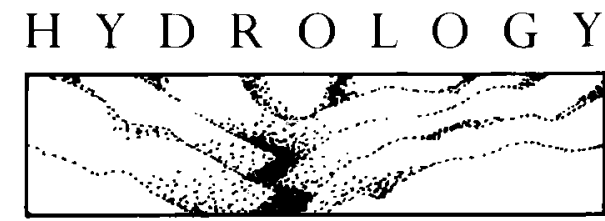

Editor: W. Berry Lyons, University of Nevada, Mackay School of Mines, Hydrology/Hydrogeology Program, Reno, NV 89557; tel. 702-784-6465

\section{Heterogeneous Porous Media in Hydrology}

PAGE 252

In natural geologic formations, flow and transport-related processes are perturbed by multidimensional and anisotropic material heterogeneities of diverse sizes, shapes, and origins (bedding, layering, inclusions, fractures, grains, for example). Heterogeneity tends to disperse and mix transported quantities and may initiate new transfer mechanisms not seen in ideally homogeneous porous media. Effective properties such as conductivity and dispersivity may not be simple averages of locally measured quantities.

The special session, "Effective Constitutive Laws for Heterogeneous Porous Media," convened at AGU's 1992 Fall Meeting in San Francisco, addressed these issue. Over fortyfive contributions, both oral and poster, covering a broad range of physical phenomena were presented. The common theme was the macroscale characterization and modeling of flow and flow-related processes in geologic media that are heterogeneous at various scales (from grain size or fracture aperture, up to regional scales). The processes analyzed in the session included coupled hydromechanical processes; Darcy-type flow in the saturated, unsaturated, or two-phase regimes; tracer transport, dilution, and dispersion. These processes were studied for either continuous (porous) or discontinuous (fractured) media.

Many presentations addressed the case of saturated porous media using statistical continuum approaches, particularly for groundwater flow and dispersive transport. There were also a number of contributions on un- 